\title{
SPRAWOZDANIE Z OGÓLNOPOLSKIEJ KONFERENCJI „OBRAZKI Z NUT. DRUKI MUZYCZNE W KULTURZE XIX I XX WIEKU”, WROCŁAW 22 LISTOPADA 2019
}

https://doi.org/10.19195/0080-3626.63.17

Konferencja poświęcona sprawom druków muzycznych, a zwłaszcza druków muzycznych XIX i XX wieku, była bardzo potrzebna z wielu względów, lecz z dwóch przede wszystkim. I mimo, że nie była to „duża” konferencja, to jej doniosłość przewyższała niejedną ,większą" konferencję. Dlaczego?

Po pierwsze, edytorstwo druków muzycznych stanowi dziś w Polsce umiarkowanie pożądany obiekt badawczy ${ }^{1}$. Od czasów publikacji Marii Przyweckiej-Sameckiej niewiele w tym zakresie się wydarzyło - w przeciwieństwie do Włoch, Francji czy Czech w Polsce druki muzyczne najczęściej traktowane są marginalnie, wybiórczo lub przyczynkowo. Nieliczne obszerniejsze prace dotyczą, tak jak i publikacje samej M. Przyweckiej-Sameckiej, dawnych druków muzycznych, rzadko kiedy wkraczając na obszar XIX wieku (chyba że dotyczy to druków Fryderyka Chopina, który siłą rzeczy nie publikował wcześniej), o wieku XX już nie wspominając. W tym zakresie jedyną jaskółką dającą nadzieję na przełamanie tego impasu była publikacja pokonferencyjna ${ }^{2}$ - pokłosie „Międzynarodowej konferencji naukowej w 70-lecie istnienia Polskiego Wydawnictwa Muzycznego", która odbyła się w 2015 roku.

Po drugie, niezmiernie cieszy mnogość wystąpień, które za tworzywo badawcze obrały tylko jeden z elementów druku muzycznego — jego okładkę. Od kilku lat możemy obserwować rozwój badań nad okładkami różnego typu i po niedawnym rozkwicie polskich badań nad okładką płyty gramofonowej przyszedł wreszcie czas na nadrobienie zaniedbań w kolejnym obszarze okładkoznawstwa. Badania nad okładką druku muzycznego do tej pory miały w Polsce znikomy dorobek. Nie tylko nie były przedmiotem osobnych rozważań ${ }^{3}$, ale nie były też postrzegane nawet służebnie jako wdzięczny materiał

1 Tak przynajmniej wynika z opisów opatrzonych odpowiednimi hasłami przedmiotowymi w Narodowym Uniwersalnym Katalogu Centralnym NUKAT (katalog.nukat.edu.pl/ [dostęp: 11.12.2019], szukaj „Temat”: Muzyka - druk $\vee$ Muzyka - edytorstwo) i „Polskiej Bibliografii Bibliologicznej" (http://mak.bn.org.pl/cgi-bin/makwww.exe?BM=12 [dostęp: 11.12.2019], szukaj „hasło_przedm”: Muzyka - druki $\vee M u z y k a$ - edytorstwo); uzupełniająco także w „Bibliografii Zawartości Czasopism”, która jednakże nie jest do końca miarodajna z uwagi na ograniczone możliwości wyszukiwania i niektóre mylące wyniki.

2 Idea - zapis - brzmienie. Międzynarodowa konferencja naukowa w 70-lecie istnienia Polskiego Wydawnictwa Muzycznego, [red. J. Puchalski], Kraków 2017.

${ }^{3}$ Dwa chlubne wyjątki, które możemy tutaj wskazać, są pokłosiami wystaw. Historia kolejny raz pokazuje więc, że gdyby nie ta forma popularyzacji okładek, prawdopodobnie w ogóle trudno byłoby mówić o literaturze okładkoznawczej w Polsce. Chodzi mianowicie o artykuł Marcina Zglińskiego (The cover design of Polish propaganda songs, 1945-1955, [w:] Music, Politics and Ideology in the Visual Arts, pod red. P. Gancarczyka, D. Grabiec, Warszawa 2015, s. 139-151) związany z międzynarodową konferencją „Music and Propaganda in the Visual Arts” (Stowarzyszenie „Liber pro Arte”, Instytut Sztuki PAN, International Musicological Society - Study Group on Musical Iconography; Warszawa 29-30 marca 2012 roku), której towarzyszyła wystawa The songs of past days. The cover design of Polish propaganda songs, 1945-1955. Drugim przypadkiem są

ROCZNIKI BIBLIOTECZNE

ROK LXIII, 2019

(C) for this edition by CNS 
dowodowy w pracach przekrojowo poświęconych projektowaniu graficznemu. Rozmaite tezy, dowody i przykłady w nich zawarte - jeśli chodzi o okładkę — posiłkowały się głównie okładką książkową, niekiedy prasową. Natomiast ze świecą szukać pracy, w której obok tych zasłużonych dla polskiego okładkoznawstwa typów okładek pojawiłyby się okładki druków muzycznych.

I oto nagle jest! Cała konferencja zaspokajająca pragnienia obu tych obszarów jednocześnie. Jest ona naturalnym echem wystawy „Obrazki z nut”, która odbyła się prawie dwa lata temu i prezentowała fragment kolekcji druków muzycznych prof. Pawła Banasia ${ }^{4}$. Przygotowanie katalogu było niezwykłą przygodą badawczą i - jak się okazało - początkiem „czegoś większego”. Sama konferencja została zorganizowana przez Pracownię Badań Pejzażu Dźwiękowego Instytutu Kulturoznawstwa Uniwersytetu Wrocławskiego w reprezentacyjnej sali 107 gmachu Instytutu Muzykologii Uniwersytetu Wrocławskiego przy ul. Szewskiej 36. Tego dnia zaplanowano dwanaście wystąpień, zgrupowanych w trzech panelach między godziną 9.00 a $15.45^{5}$.

Konferencję otworzyła, a następnie poprowadziła pierwszą jej sesję, dr hab. prof. UWr Renata Tańczuk (Instytut Kulturoznawstwa UWr). Wystąpienie Stów kilka o drukach muzycznych jako przedmiocie badań humanistycznych wprowadziło uczestników programowo w zagadnienie oraz nakreśliło możliwe perspektywy badawcze. Spory nacisk został położony na powiązanie druków muzycznych z pojęciami „kolekcjonerstwo” oraz „,obiekt aksjosemiotyczny", to jest taki, który jest obiektem nie tylko informacyjno-komunikacyjnym (takimi są obiekty semiotyczne), lecz także symbolem uobecniającym pewne wartości i znaczenia w ujęciu psychologicznym i psychospołecznym. Właśnie takie podejście stanowi podstawę programu badań prowadzonych przez Pracownię organizującą konferencję — badane przez nią druki muzyczne są nośnikami „znaczeń i wartości, których analiza ujawnia między innymi przemiany preferencji estetycznych, muzycznych, przyjmowane wyobrażenia płci kulturowej, tożsamości narodowej oraz obcych kultur’6. Przeprowadzone w ramach badań rozpoznanie pokazało, że z całą pewnością druki muzyczne są w Polsce niedocenionym źródłem do badań humanistycznych nad kulturą popularną epoki, mimo że uważny badacz odnajdzie w nich wiele potrzebnych faktów i informacji. Możemy więc tylko podziwiać i pozazdrościć na przykład bazy Illustrated sheet music ${ }^{7}$, której towarzyszy

teksty wprowadzające Renaty Tańczuk oraz Pawła Banasia do katalogu wystawy (Obrazki z nut. Druki muzyczne od końca XIX do połowy XX wieku z kolekcji Pawła Banasia. Wystawa w Dolnośląskiej Bibliotece Publicznej im. Tadeusza Mikulskiego we Wrocławiu. Styczeń/luty 2018, red. J. Czarnik, A. Ćwik, Wrocław 2018).

${ }^{4}$ Więcej na ten temat zob. J.M. Łubocki, Okładki druków muzycznych jako ważne zagadnienie badawcze: na marginesie wystawy „Obrazki z nut” (Wrocław, 19 stycznia-28 lutego 2018), „Studia o Książce i Informacji” 37, 2018, s. 215-219.

5 Przy omawianiu przebiegu sympozjum zastosowano następujące skróty nazw instytucji: AMWr - Akademia Muzyczna we Wrocławiu; ASPWr - Akademia Sztuk Pięknych we Wrocławiu; BUWr - Biblioteka Uniwersytecka we Wrocławiu; UWr - Uniwersytet Wrocławski.

${ }^{6}$ Aksjosemiotyka druków muzycznych, http://pracownia.audiosfery.uni.wroc.pl/pracownia/ projekty-badawcze/aksjosemiotyka-drukow-muzycznych/ [dostęp: 12.12.2019].

7 Illustrated sheet music, http://imagesmusicales.be [dostęp: 12.12.2019]. W bazie zgromadzono opisy i podobizny ilustrowanych nut, głównie z lat 1890-1940 i w stylu secesji lub art déco, 
blog Images Musicales stories ${ }^{8}$, od 2014 roku regularnie publikujący tematyczne artykuły opierane na zawartości bazy, ale nie tylko; albo publikacji The Collector's Book of Sheet Music Covers ${ }^{9}$, która na przykładzie zbiorów Australijskiej Biblioteki Narodowej ukazuje, jak australijskie piosenki i muzyka odzwierciedlają poczucie Australijczyków jako narodu. Co więcej, nowe nurty humanistyczne - kolekcjonerstwo, studia nad kulturą wizualną, studia genderowe, studia postkolonialne — wraz z własnym rozwojem będą stawiać coraz więcej pytań. Udzielenia odpowiedzi na nie będą jednak oczekiwać od okładkoznawców, kulturoznawców i muzykologów. Według R. Tańczuk powinniśmy być na to gotowi. Następnie prof. em. Paweł Banaś (Instytut Historii Sztuki UWr), spiritus movens całego przedsięwzięcia, z właściwą sobie swadą i erudycją, w towarzystwie pokazu slajdów z okładkami oraz odtworzonych utworów muzycznych, w wystąpieniu zatytułowanym Samotna harmonia opowiedział o historii swoich badań (,niespodziewanych zainteresowań” — jak wyraził się sam prelegent), które nigdy nie koncentrowały się na centrum, lecz na niesłusznie deprecjonowanych peryferiach historii sztuki, w tym badaniach nad okładkami druków muzycznych, których zaczątkiem był zbiór kilkudziesięciu nut na akordeon, przekazany mu przez znajomego.

Następnie Jakub Maciej Łubocki (Instytut Informacji Naukowej i Bibliotekoznawstwa UWr) przedstawił Okładki druków muzycznych na tle ogólnej teorii okładkoznawstwa. Teoria ta, propagowana przez prelegenta od 2015 roku, zakłada wyodrębnienie badań nad elementami ochronnymi dokumentów do wspólnego obszaru badawczego. Umieszczone w nim trzy dyscypliny - oprawoznawstwo, introligatorstwo i okładkoznawstwo - powiązane z sobą historycznie i funkcjonalnie, powinny rozwijać badania nad zagadnieniami opraw indywidualnych, okładek (to jest opraw nakładowych) i sposobów ich łączenia z zasadniczym blokiem dokumentu w ujęciu funkcjonalnym. O ile pierwsza i ostatnia dyscyplina mają już pewien ugruntowany dorobek i miejsce w panteonie nauk, o tyle okładkoznawstwo nie było do tej pory postrzegane jako samodzielna dyscyplina. J.M. Łubocki swoimi wystąpieniami i publikacjami próbuje zmienić ten stan rzeczy, zauważając jednocześnie, że typ dokumentu wpływa na sposób istnienia danej okładki. W związku z tym w swoim referacie, po przedstawieniu ogólnych założeń teorii okładkoznawstwa, skupił się na funkcjach charakterystycznych dla okładek druków muzycznych.

$\mathrm{Na}$ koniec sesji Anita Wincencjusz-Patyna (Katedra Historii Sztuki i Filozofii ASPWr) przedstawiła wystąpienie pod tytułem Kolory tonacji, nie zawsze pięciolinie. Polska szkoła ilustracji a druki muzyczne. Na podstawie tytułów ukazujących się w Polskim Wydawnictwie Muzycznym (Leopold Tyrmand, U brzegów jazzu; Maria Kaczurbina, Lech Miklaszewski, Elementarz muzyczny. Nasze pierwsze nutki), Biurze Wydawniczym „Ruch” (Jadwiga Gorzechowska, Flisacy, Szeroka woda, Polski roczek; Hanna Januszewska, Grajmy) i Naszej Księgarni (Jadwiga Gorzechowska, Maria Kaczurbina, Tatry, moje Tatry, Na tym naszym Śląsku, Niedaleko od Rzeszowa) omówiła intensywny polski ruch wydawniczy w okresie Polski Rzeczpospolitej Ludowej, który zauważalnie

pochodzących z różnych krajów. Podstawę bazy stanowi prywatna kolekcja, zasobna w ponad 10 tysięcy obiektów.

${ }^{8}$ Images Musicales stories. 'Ceci et ça' about illustrated sheet, http://blog.imagesmusicales. be/ [dostęp: 12.12.2019].

9 R. Holmes, R. Lee-Martin, The Collector's Book of Sheet Music Covers, Canberra 2001.

ROCZNIKI BIBLIOTECZNE

ROK LXIII, 2019

(C) for this edition by CNS 
zaznaczył się także w obszarze druków muzycznych, ilustrowanych pracami takich uznanych artystów jak Jerzy Skarżyński, Andrzej Darowski, Zofia Darowska, Andrzej Kowalski, Józef Wilkoń czy Zbigniew Rychlicki. Towarzyszący wystąpieniu pokaz slajdów pozwolił dostrzec wysoki poziom, oryginalność i różnorodność ówczesnych realizacji.

Drugą sesję prowadził dr Sławomir Wieczorek z Zakładu Antropologii Muzycznej Instytutu Muzykologii UWr. Sesję tę rozpoczęło wystąpienie Wiolety Muras (Instytut Muzykologii UWr) na temat Szaty graficznej okładek pieśni masowych i piosenek rozrywkowych wydanych w 1954 roku przez Polskie Wydawnictwo Muzyczne. Wysyp piosenek masowych właśnie w tym roku (już po śmierci Józefa Stalina) prelegentka przypisuje oddolnym decyzjom wydawnictw. W tym czasie przydział papieru na druk był narzędziem kontroli i przymusu stosowanym przez ówczesne władze. Wydawnictwa, chcąc prawdopodobnie uniknąć problemów z dostawą papieru, samodzielnie zadecydowały więc o publikowaniu repertuaru zgodnego z wcześniejszą linią władzy, mimo że śmierć J. Stalina powinna wpłynąć na większą swobodę w doborze repertuaru wydawniczego. Badania tych druków pozwoliły zidentyfikować takich ilustratorów jak Kazimierz Wojtanowicz, Tadeusz Jodłowski, Janusz Bruchnalski, Witold Skulicz, Jan Kurkiewicz i Andrzej Darkow (ten ostatni był dla Muras zagadką, gdyż nie udało się go odnaleźć w żadnych biograficznych źródłach informacji; w trakcie dyskusji A. Wincencjusz-Patyna zasugerowała jednak, że Andrzej Darkow może być w istocie pseudonimem Andrzeja Darowskiego — to cenna hipoteza warta dalszych badań). Ustalono, że okładki tych kategorii druków muzycznych (w trakcie badań prelegentka uznała za stosowne wyróżnić jeszcze jedną, oprócz dwu już wymienionych w tytule wystąpienia, kategorię pieśni wojskowych) były mocno nacechowane plakatowo. Niektóre zaskakiwały podobieństwem ukształtowania graficznego, często w warstwie treściowej ilustracje czerpały wprost $\mathrm{z}$ tekstu ilustrowanej piosenki (elementy miejskiej architektury, wiejskich krajobrazów, konkretnych scen ze zwrotek; w piosenkach warszawskich chętnie wykorzystywanym motywem były ukończone właśnie budynki podniesione z ruin). Mimo że wszystkie badane druki znamionował typowy wachlarz stylowy epoki (socrealizm), wiele z nich prezentowało bardzo wysoki poziom. Poruszono także zagadnienie warstwy informacyjnej okładek i jej specyfikę.

Następnie Michał Witek (Instytut Kulturoznawstwa UWr) w wystąpieniu ,Wschód jest czerwony" - Chińska rewolucja na plakacie i w muzyce przedstawił druki muzyczne jako źródło do badań nad wielką proletariacką rewolucją kulturalną w Chinach (19661976). Muzyka była wówczas bezcennym narzędziem dla komunistycznej propagandy. Z powodu dużego stopnia analfabetyzmu wśród ludności chińskiej wizualizacja treści muzycznej w formie graficznej stanowiła istotny element tej propagandy, którego oddziaływanie znacznie wykraczało poza dotychczas stosowane metody. Druki muzyczne w Chinach tego okresu służyły także umacnianiu jedności narodowej (Chiny do dziś są krajem wieloetnicznym i wielojęzycznym, z czego nie zawsze zdajemy sobie dostatecznie sprawę). U podstaw tych koncepcji legło pojęcie nowej muzyki (chiń. xin yinyue), wyrażone po raz pierwszy przez Lü Ji w 1936 roku $^{10}$. W ten sposób dominującym nurtem owych

10 Więcej na ten temat zob. L. Pisano, Taiwanese composers and piano works in the XX century: Traditional Chinese culture and the Taiwan xin yinyue, „Kervan. International Journal of Afro-Asiatic Studies” 2005, nr 1, s. 49-71, tu: s. 51-53; DOI: 10.13135/1825-263X/897.

ROCZNIKI BIBLIOTECZNE

ROK LXIII, 2019

(C) for this edition by CNS 
czasów stała się muzyka polityczna (patriotyczna lub rewolucyjna) — także dlatego, że wiele form muzyki (na przykład tradycyjna muzyka chińska, opera pekińska, klasyczna muzyka zachodnia i popularna) było zakazanych w epoce maoizmu. Całości towarzyszył pokaz slajdów prezentujących muzykę na plakatach, znaczkach pocztowych, płytach gramofonowych i wkładkach do płyt z epoki. Szczególnie plakaty miały na celu mobilizowanie, informowanie, gratulowanie, inspirowanie, pouczanie lub uspokajanie ludzi.

W dalszej kolejności Kamila Staśko-Mazur (Instytut Muzykologii UWr) omówiła Oprawę graficzną twórczości użytkowej Władysława Szplimana (1911-2000), a więc warstwę edytorską jego piosenek rozrywkowych, rewiowych, masowych oraz dziecięcych, starając się jednocześnie odpowiedzieć na pytania, czy znajdujemy jakieś zarysowujące się tendencje w tej oprawie oraz czy sam kompozytor był zainteresowany szatą graficzną druków utrwalających jego dzieła. Zwłaszcza ten drugi aspekt okazał się intrygujący, albowiem z rozmowy z żoną kompozytora, do której K. Staśko-Mazur dotarła, wynika, że nie był on zainteresowany tą kwestią — w 1954 roku wypowiedział się następująco: „Niezbędne jest przejście wydawnictwa muzyki rozrywkowej i tanecznej na operatywność gazetową chociażby kosztem dbałości o szatę graficzną". Było to spowodowane nie tyle lekceważeniem strony graficznej swoich dzieł, ile troską o merkantylny aspekt ich wydawania - w owym czasie nuty często wydawano tak późno, że sława danej piosenki zdążyła już przebrzmieć i sprzedażność nut do niej wyraźnie malała. Jako ciekawostkę trzeba podać także, że pierwszy utwór W. Szpilmana znamy jedynie z rękopisu i nagrania — badaczce do tej pory nie udało się bowiem natrafić na ślad jego druku.

Na koniec Krzysztof Niźnik w wystąpieniu Okładka płytowa, czyli muzyka w otulinie plastyki syntetycznie przedstawił kategorie elementów graficznych znajdujących się na okładkach płyt dźwiękowych (identyfikacja artysty, miejsca wykonania, wydawnictwa, serii wydawniczej oraz plastyczne odzwierciedlenie muzyki).

Sesję trzecią poprowadziła wzmiankowana już dr Anita Wincencjusz-Patyna. W sesji tej jako pierwsza wystąpiła Joanna Konopczak (Oddział Zbiorów Muzycznych BUWr), która w referacie Zatrzymane w czasie. Wartość historyczna szaty graficznej druków muzycznych z kolekcji Biblioteki Uniwersyteckiej we Wrocławiu przedstawiła występujące na tych drukach osoby (Fritzi Massary, Gerhart Fischer, Julius Emil Leonhardt, Alexander Girardi) i miejsca (Śnieżka, główny pawilon Śląskiej Wystawy Rzemiosła i Przemysłu w 1881 roku, wieża widokowa na Śnieżniku, pałac w Kamieńcu Ząbkowickim, pomnik Wilhelma I). Druki te szczególną wartość przejawiają tam, gdzie jest to jedyny znany widok na osobę lub miejsce bądź też zaświadczają stan budowli w danym momencie nuty, wydawane o wiele szybciej niż monografie, są świadkami epoki.

Następnie Magdalena Wiącek (Biblioteka AMWr) zaprezentowała Grafikę okładek druków muzycznych opublikowanych w oficynie Leona Idzikowskiego - wprowadzenie do zagadnienia. Wystąpienie to, przedstawiające losy tej oficyny, miało wielopłaszczyznowe znaczenie symboliczne — odbyło się w 160. rocznicę powstania oficyny, 70-lecie Biblioteki Akademii Muzycznej we Wrocławiu i 30-lecie pracy zawodowej prelegentki. Z ciekawostek trzeba podać, że założona przy wydawnictwie w 1870 roku biblioteka z czytelnią, zawierająca również dział nut, pod koniec XIX wieku stanowiła największy zbiór druków muzycznych w Rosji. Reprezentował on bogaty repertuar muzyczny produkowany przez oficynę, jednak trudno opisać jego charakter, katalogi podawały bowiem nie tylko druki 
wydane przez oficynę, lecz także druki innych wydawców dostępne w składzie. M. Wiącek szacuje, że L. Idzikowski i jego spadkobiercy mogli wydać około 1200 dokumentów. Wystąpieniu towarzyszyły nuty ze zbiorów Biblioteki, które pochodzą z darowizny o proweniencji lwowskiej - Marii i Walerii Jędrzejewskich.

Wystąpienie Zbigniewa J. Przerembskiego (Instytut Muzykologii UWr) — Przedstawienia muzyczne $w$ ilustracjach zbiorów polskich pieśni ludowych wydanych $w$ drugiej połowie XX wieku — z powodu nieobecności prelegenta zaprezentowała Joanna Gul. Dotyczyło ono ogólnopolskiej Akcji Zbierania Folkloru Muzycznego (1950-1954), finansowanej przez Ministerstwo Kultury i Sztuki, a przeprowadzonej przez Państwowy Instytut Sztuki we współpracy z Polskim Radiem. Jej pokłosiem były liczne publikacje przedstawiające instrumenty, folklor etnomuzyczny regionów (na przykład obrzędy, stroje) czy treść pieśni. Druki te ozdabiano różnymi formami ilustracji: od drobnych elementów zdobniczych po całostronicowe grafiki. Szczególnie interesująca jest ich ahistoryczność lub niewiarygodność w niektórych przypadkach (przykładowo w tomach Od Tatr do Bałtyku, zestawionych przez Adolfa Chybickiego, jeden z muzykantów gra na dudach podhalańskich, mimo że jego strój nie pochodzi z Podhala; harfa obecna na innej ilustracji nie jest zaś instrumentem znanym w historii polskiej muzyki ludowej). Można jednocześnie wskazać publikacje ilustrowane wiernie, na przykład Szlakiem kozła lubuskiego Jadwigi i Mariana Sobieskich. W podsumowaniu stwierdzono, że ilustracje w tego rodzaju publikacjach mają walor bardziej artystyczny niż merytoryczny, gdyż najprawdopodobniej zabrakło konsultacji etnomuzykologicznej, a artyści graficy nie mieli świadomości właściwości folkloru muzycznego poszczególnych regionów Polski.

Za sprawą osoby prelegentki płynnie przeszliśmy do ostatniego wystąpienia, a mianowicie Instrumentów muzycznych na okładkach nut przedstawionego właśnie przez Joannę Gul (Biblioteka Kulturoznawstwa i Muzykologii UWr), w którym na przykładzie zbiorów nut Biblioteki, zbiorów własnych oraz Andrzeja Dorędy, a także wzmiankowanej już na wstępie bazy Illustrated sheet music zostały przedstawione przykłady frontyspisów, winiet, sygnetów drukarskich oraz okładek pełnoilustrowanych z motywem instrumentu muzycznego. Okazało się, że najpopularniejszym z nich jest lira/barbiton/kitara — instrument poza starożytnością zapomniany, a na przedstawieniach nut wprost przeciwnie: szalenie popularny. W dalszej kolejności pojawiły się: lira korbowa, kamerton, lutnia, skrzypce, harfa, fortepian, gitara, bałałajka, ukulele, kontrabas, puzon, banjo i wiolonczela. Z konkluzji referatu mogliśmy dowiedzieć się, że zniekształcenia instrumentów muzycznych w grafice są dosyć częste, lecz sama obecność instrumentów na okładkach nut jest oczywistością.

W podsumowaniu konferencji należy podkreślić, że została ona zorganizowana w bardzo sprawny sposób, a wszystkie wystąpienia prezentowały wysoki poziom odpowiadający stopniowi zapotrzebowania na nie. Pozostaje mieć nadzieję, że owo „coś większego", wspomniane na samym początku, będzie przez wrocławskie kulturoznawstwo i muzykologię rozwijane i już wkrótce będziemy mogli mówić o narodzinach nowej szkoły badań - aksjosemiotycznej szkoły badań druków muzycznych. To mogą uczynić tylko kolejne badania, konferencje i publikacje. Zatem do dzieła!

Jakub Maciej Łubocki

ROCZNIKI BIBLIOTECZNE

ROK LXIII, 2019

(C) for this edition by CNS 